\title{
EKSISTENSI INSTRUMEN EKONOMIK TERHADAP GOOD ENVIRONMENTAL GOVERNANCE
}

\author{
Joejoen \\ Tjahjanijoejoen668@gmail.com \\ Fakultas Hukum UniversitasIslamLamongan
}

\begin{abstract}
ABSTRAK
Instrumen ekonomik merupakan salah satu instrumen hukum lingkungan yang pengaturannya lebih dipertegas dalam UUPPLH yaitu pada Bab V Paragraf 8 Pasal 42 dan Pasal 43. Sedangkan good environmental governance merupakan pengembangan dari good governance dalam konservasi lingkungan hidup. Penelitian ini mengupas bagaimana eksistensi instrumen ekonomik dalam mengimbangi proses tata kelola lingkungan hidup yang berprinsip inklusivitas, akuntabilitas, efisiensi, efektivitas dan keadilan social yang membentuk dasar dari good governance sehingga tercapai good environmental governance yang dapat merefleksikan pemahaman terbaik dari struktur, fungsi, proses dan variabilitas yang terkait dan sesuai dengan system alam (ekosistem). Denganmetode penelitianyuridisnormative diperoleh hasilanalisa berdasarpada pendekatan perundangundangan dan pendekatankonseptual. Ketentuan pengaturan instrumen ekonomik akhirnya tertuang dalam Peraturan Pemerintah No. 46 Tahun 2017 tentang Instrumen Ekonomi lingkungan hidup sesuai mandat Undang-Undang No. 32 Tahun 2009 tentang Perlindungan dan Pengelolaan Lingkungan Hidup, setelah sebelumnya terdapat pada beberapa peraturan perundang-undangan.
\end{abstract}

\section{KataKunci : Instrumen ekonomik, good environmental governance}

\section{PENDAHULUAN}

Hukum lingkungan adalah semacam "toolbox" yang berisi susunan teknik atau instrumen pengaturan. Secara hukum sebagian besar berdasarkan pendekatan tradisional, yaitu berupa penggunaan sarana langsung, biasanya menunjuk pada "command and control". Terdapat dua karakteristik pokok system pengaturan langsung. Pertama, otoritas yang berwenang akan menentukan baku mutu lingkungan atau sasaran yang harus dipatuhi. Karakteristik pertama ini yang disebut dengan "command". Kedua, ketidaktaatan terhadap baku mutu lingkungan atau sasaran yang telah ditetapkan akan timbul reaksi, yaitu ancaman sanksi yang bersifat negatif, 
seperti penuntutan pidana di pengadilan.

Karakteristik kedua inilah yang disebut "control". 1

Disamping sarana pengaturan langsung, hukum lingkungan juga menyediakan instrumen kebijakan lain yang disebut instrumen berdasarkan mekanisme pasar (market-based) atau instrumen ekonomik. Instrumen ekonomik misalnya, pajak, subsidi, dan skema dagang (trading scheme) yang digunakan untuk men-tackle isu-isu, seperti emisi gas rumah kaca, produksi limbah, dan konservasi habitat. Ecolabelling dan analisis mengenai dampak lingkungan adalah sangat penting untuk menjamin keterbukaan informasi lingkungan, dan juga beberapa instrumen yang bersifat sukarela yang mencakup sistem pengelolaan lingkungan, audit lingkungan, dan laporan lingkungan merupakan pendekatan yang bersifat fleksible untuk mencapai target perlindungan lingkungan. ${ }^{2}$

Frans H. Oosterhuis et al, membedakan instrumen hukum lingkungan menjadi tiga kategori, yaitu economic instruments, direct regulative instruments, dan comunicatif instruments. Economic instruments adalah instrumen

\footnotetext{
${ }^{1}$ A'an Efendi, SH, MH, Hukum Lingkungan : Instrumen Ekonomik dalam Pengelolaan Lingkungan di Indonesia dan Perbandingannya dengan Beberapa Negara, PT. Citra Aditya Bakti, Bandung, 2014, h. 33

${ }^{2}$ Ibid.
}

yang dipengaruhi oleh kondisi pasar pada saat orang dan perusahaan-perusahaan membuat keputusan, tanpa secara langsung mengurangi ruang keputusan yang tersedia untuk mereka. Direct regulative instruments adalah instrumen yang dipengaruhi oleh tingkatan pilihanpilihan dengan sarana berupa laranganlarangan (prohibitions), pembatasanpembatasan(restrictions), atau kewajibankewajiban (obligations). Istilah lain untuk direct regulative instruments adalah "command and control" regulations. Communicative instruments adalah instrumen yang bertujuan untuk penyesuaian secara sukarela terhadapperilaku individual atau kelompok untuk lebih ramah lingkungan. Pelanggaran berat yang dilakukan terhadap lingkungan umumnya dilakukan oleh industri besar, yang jelas dimiliki oleh golongan ekonomi sangat kuat. Jadi, kejahatan lingkungan yang berat umumnya dilakukan golongan “white collar". Upaya mengatasi masalahmasalahlingkunganhidupkianmendapatper hatianluasdewasa ini.Pendekatanekonomi melalui penerapaninstrumenekonomi adalah salah satu jalan keluaryangdiajukanuntukmengatasi persoalan-persoalan seperti pencemaranlingkungan,

\footnotetext{
${ }^{3}$ Ibid. h. 34
} 
kerusakansumberdayaalam,danperubahani klim.Pada

bulanNovember $2017,{ }^{4}$ Pemerintah

RepublikIndonesia

menerbitkanPeraturanPemerintahNomor4

6 tahun2017 tentang InstrumenEkonomi

LingkunganHidup.PenyusunanPeraturanP

emerintahini adalah mandatdari Undang-

UndangNomor32

tahun2009

tentangPerlindungandanPengelolaan

Lingkungan Hidup.Tujuan dari Peraturan

Pemerintahtentang Instrumen Ekonomi

LingkunganHidup(selanjutnya disebutPP

IELH), sebagaimana

tertulisdalamPeraturan Pemerintah ini, adalah untuk (a)menjamin akuntabilitas dan penataan hukum dalam penyelenggaraanperlindungandanpengelol aanlingkunganhidup; (b) mengubahpola pikir dan perilaku pemangku kepentingan dalampembangunan dan kegiatan ekonomi.(c) mengupayakan pengelolaan pendanaan Lingkungan Hidup yang sistematis,teratur, terstruktur,danterukur; dan(d) membangundanmendorong kepercayaanpublikdan internasional dalampengelolaan Pendanaan Lingkungan Hidup.

$\begin{array}{lcr}\text { Tonggak } & \text { sejarah } & \text { kebijakan } \\ \text { pengelolaan } & \text { lingkungan } & \text { hidup }\end{array}$

4 A. Hamzah, DR., SH, Penegakan Hukum Lingkungan, Arikha Media Cipta, Jakarta.h. 77

${ }^{5}$ https://wri-indonesia.org , events , kuliahumum-dan-diskusi-instrumen-e. menunjukkan bahwa pada tahun 2001 telah terdapat upaya pengembangan "good governance" dalam konservasi lingkungan hidup, sehingga bersinergi dengan tujuan dikeluarkannya PeraturanPemerintahNomor46 tahun2017 tentang InstrumenEkonomi LingkunganHidup. Dalam hal ini pemerintah dituntut adanya hubungan kegiatan antara negara, swasta dan masyarakat sebagai proses kegiatan dalam memecahkan masalah bersama dalam memenuhi kebutuhan masyarakat dengan melibatkan seluruh pelaku (stakeholders) yang berkepentingan. Bank dunia (world bank) mendefinisikan good governance sebagai suatu penyelenggaraan manajemen pembangunan yang solid dan bertanggungjawab dan sejalan dengan prinsip demokrasi serta pasar yang efisien. Apabiladikaitkan dengan perlindungan dan pengelolaan lingkungan hidup, maka goodgovernance menjadi good environmental governance yaitu suatu prinsip penyelenggaraan

6 M.Chazienul Ulum, Rispa Ngindana, Environmental Governance : Isu, Kebijakan, dan Tata Kelola Lingkungan Hidup, UB Press, Malang, 2017.h. 43.

\footnotetext{
7 Dinoroy Marganda Aritonang, $\mathrm{SH}, \mathrm{MH}$, Aspek Hukum Penyelenggaraan Administrasi Publik di Indonesia, PT. Refika Aditama, Bandung, 2019. h.188.

dikaitkan dengan perlindungan dan pengelolaan lingkungan hidup, maka good
} 
pemerintahan yang baik dalam pengelolaan lingkungan hidup.

Dengan diterbitkannya PP IELH ini instrumen ekonomik dalam lingkungan hidup dapat menunjukkan bagaimana eksistensinya mendukung tercapainya good environmental governance, setelah sebelumnya diatur dalam berbagai peraturan perundang-undangan.

\section{METODE PENELITIAN}

Tipepenelitianhukumyang

dilakukan adalahyuridisnormatif (hukum normatif).

Metode

penelitianhukumnormatif adalah

suatuprosedurpenelitianilmiahuntuk

menemukan kebenaranberdasarkan logika keilmuanhukumdarisisinormatifnya. Oleh karenaitu penelitian hukum inidifokuskan untukmengkajipenelitian hukumtentang kaidah-kaidah atau norma-norma dalam hukumpositif,yakninorma hukumyang terkait dengan instrumen ekonomik lingkungan hidup. Oleh karena tipepenelitianyang digunakanadalahtipe penelitianyuridisnormatif,maka pendekatan yangdigunakanadalahpendekatanperundan $\mathrm{g}-$ undangan(statute approach).Pendekatan tersebutmelakukan pengkajian peraturan perundang-

\footnotetext{
${ }^{8}$ JohnnyIbrahim,Teori \&MetodePenelitianHukum Normatif, Banyumedia Publishing, Malang, 2006, h. 57.
}

undanganyang berhubungan dengan pokok permasalahan.

\section{HASIL PENELITIAN} DAN PEMBAHASAN

Penggunaan instrumen ekonomik dalam pengelolaan lingkungan tertuang dalam :

1. Prinsip 17 Deklarasi Rio.

2. Agenda 21, Chapter 33 Financial, and Resources and Mechanism.

3. Draft International Convenant on Environment and Development.

Menurut Syahrul Machmud di Indonesia melalui Undang-Undang Nomor 23 Tahun 1997 secara umum memberikan peluang bagi pengembangan teori ekonomi, seperti pada Pasal 10 mewajibkan pemerintah untuk mengembangkan dan menerapkan perangkat yang bersifat preemtif, preventif dan proaktif dalam upaya pencegahan penurunan daya dukung dan daya tampung lingkungan hidup. Perangkat preventif disini salah satunya adalah penggunaan instrumen ekonomi. Pasal inilah yang memberikan payung hukum (umbrella law) bagi pengembangan pelaksanaan kebijakan instrumen ekonomi secara rinci. Dalam Undang-Undang Nomor 32 Tahun 2009 hal ini lebih diperkuat pada Pasal 42 sampai 43 yang mengatur tentang instrumen ekonomi lingkungan hidup. Bentuk instrumen tersebut adalah 
perencanaan pembangunan dan kegiatan ekonomi, pendanaan lingkungan hidup, dan insentif dan/atau disinsentif. Pendanaan lingkungan hidup berupa dana jaminan pemulihan lingkungan hidup, dana penanggulangan pencemaran dan/atau kerusakan dan pemulihan lingkungan hidup, dan dana amanah/bantuan untuk konservasi.

Walaupun belum dilaksanakan secara konsisten, pendekatan kerjasama dan bantuan teknis sebagai manifestasi pendekatan perilaku juga dikembangkan dalam konteks Program Peringkat Kinerja Usaha (PROPER) dan program pemberian bantuan pendanaan (program pinjaman lunak) bagi industri melakukan upaya pengendalian pencemaran (PAE-OECF). Kedua program ini dilaksanakan oleh BAPEDAL pusat. Dalam pelaksanaan Proper perusahaan-perusahaan yang mendapatkan rating tidak baik pada kenyataannya banyak yang digiring untuk memperbaiki diri melalui program audit lingkungan dengan janji tidak akan

\section{Instrumen Ekonomik dalam Undang-}

Undang Lingkungan Hidup (UULH)

Nomor 4 Tahun 1982.

Pada saat berlakunya UULH tidak terdapat pengaturan secara khusus tentang instrumen ekonomik. Instrumen

\footnotetext{
${ }^{9}$ Syahrul Machmud, DR., SH, Penegakan Hukum Lingkungan Indonesia, Graha Ilmu, Yogyakarta.h.160.
}

ekonomik terdapat dalam ketentuan Pasal 10 ayat (3) UULH yang menyebut tentang pajak dan retribusi lingkungan.

1. Instrumen Ekonomik dalam Undang-Undang Nomor 23 Tahun 1997 tentang Pengelolaan

\section{Lingkungan Hidup (UUPLH).}

Pada saat berlakunya UUPLH satusatunya ketentuan tentang instrumen ekonomik mungkin dapat ditafsirkan berdasarkan ketentuan Pasal 8 ayat (2) huruf c yang menyatakan :

"mengembangkan pendanaan bagi upaya pelestarian fungsi lingkungan hidup sesuai peraturan perundang-undangan yang berlaku."

\section{Instrumen Ekonomik dalam}

Undang-Undang Nomor 32 Tahun 2009 tentang Perlindungan dan Pengelolaan Lingkungan Hidup (UUPPLH).

UUPPLH mengatur dengan tegas instrumen ekonomik dalam $\mathrm{BAB} \mathrm{V}$ Pengendalian Paragraf 8 dengan judul Instrumen Ekonomi Lingkungan Hidup, yang meliputi :

1) Perencanaan pembangunan dan kegiatan ekonomi;

2) Pendanaan lingkungan hidup;

3) Insentif dan/atau disinsentif. Penjelasan tentang ketiga jenis instrumen ekonomi lingkungan hidup diatas terdapat dalam penjelasan Pasal 42 ayat (2) UUPPLH.Menurut ketentuan Pasal 43 ayat (1) UUPPLH, instrumen ekonomi 
lingkungan hidup yang berwujud perencanaan pembangunan dan kegiatan ekonomi meliputi :

a. Neraca sumber daya alam dan lingkungan hidup;

b. Penyusunan produk domestic bruto dan produk domestic regional bruto yang menyangkut penyusutan sumber daya alam dan kerusakan lingkungan hidup;

c. Mekanisme kompensasi/imbal jasa lingkungan hidup antardaerah; dan

d. Internalisasi biaya lingkungan hidup. Instrumen ekonomi lingkungan hidup yang berwujud pendanaan lingkungan hidup meliputi :

1) Dana jaminan pemulihan lingkungan hidup adalah dana yang disiapkan oleh suatu usaha/atau kegiatan untuk pemulihan kualitas lingkungan hidup yang rusak karena kegiatannya.

2) Dana penanggulangan pencemaran dan/atau kerusakan dan pemulihan lingkungan hidup adalah dana yang digunakan untuk menanggulangi pencemaran dan/atau kerusakan lingkungan hidup yang timbul akibat suatu usaha dan/atau kegiatan.

3) Dana amanah/bantuan untuk konservasi adalah dana yang berasal dari sumber hibah dan donasi untuk kepentingan konservasi lingkungan hidup.

Instrumen ekonomi lingkungan

hidup yang berwujud insentif dan/atau disinsentif, antara lain diterapkan dalam bentuk :

1) Pengadaan barang dan jasa yang ramah lingkungan hidup;

2) Penerapan pajak, retribusi, dan subsidi lingkungan hidup;

3) Pengembangan system lembaga keuangan dan pasar modal yang ramah lingkungan hidup;
4) Pengembangan system perdagangan izin pembuangan limbah dan/atau emisi;

5) Pengembangan system pembayaran jasa lingkungan hidup;

6) Pengembangan asuransi lingkungan hidup;

7) Pengembangan system label ramah lingkungan hidup; dan

8) System penghargaan kinerja di bidang perlindungan dan pengelolaan lingkungan hidup.

Pengaturan instrumen ekonomik juga terdapat dalam ketentuan Pasal 55 UUPPLH.

\section{Instrumen Ekonomik dalam Undang-} Undang Nomor 27 Tahun 2003 tentang panas bumi.

Pengaturan instrumen ekonomik terdapat dalam ketentuan Pasal 29 yang mewajibkan kepada pemegang izin usaha pertambangan panas bumi untuk mengelola lingkungan hidup yang mencakup pencegahan dan penanggulangan pencemaran serta pemulihan fungsi lingkungan hidup dan menyediakan dana untuk reklamasi lahan bekas tambang setelah kegiatan pertambangan selesai. Kewajiban menyediakan dana untuk reklamasi lahan bekas tambang adalah perwujudan instrumen ekonomik dalam pengelolaan lingkungan pertambangan panas bumi.

\section{Instrumen ekonomik dalam Undang-} Undang Nomor 4 Tahun 2009 tentang Pertambangan Mineral dan Batu Bara. 
Dalam Undang-Undang Nomor 4

Tahun 2009 ketentuan instrumen ekonomik diatur pada Pasal 100 dan 101. Pasal 100 Undang-Undang Nomor 4 Tahun 2009 mewajibkan kepada pemegang IUP dan IUPK untuk menyediakan dana jaminan yang nantinya dipergunakan untuk kegiatan reklamasi dan pascatambang. Pada prinsipnya kegiatan reklamasi dan pascatambang dilakukan oleh pemegang IUP dan IUPK. Namun, reklamasi dan pascatambang dapat dilakukan oleh pihak ketiga yang ditetapkan oleh gubernur atau bupati/walikota sesuai dengan kewenangannya jika pemegang IUP dan IUPK tidak melaksanakan reklamasi dan pascatambang. Reklamasi dan pascatambang oleh pihak ketiga ini dilakukan dengan menggunakan dana jaminan yang dibayarkan oleh pemegang IUP dan IUPK.

Peraturan Pemerintah sebagaimana dimaksud Pasal 101 Undang-Undang Nomor 4 tahun 2009 adalah Peraturan Pemerintah Nomor 78 Tahun 2010 tentang reklamasi dan pascatambang. Ketentuan tentang jaminan reklamasi diatur dalam Pasal 29 - Pasal 36. Sedangkan ketentuan

${ }^{10}$ M. Chazienul Ulum, Rispa Ngindana, Environmental Governance : Isu, Kebijakan, dan Tata Kelola Lingkungan Hidup, UB Press, Malang, 2017.h.131. mengenai jaminan pascatambang diatur dalam Pasal 37-Pasal 43.

\section{Instrumen ekonomik dalam Undang-Undang Nomor 18 Tahun 2008 tentang Pengelolaan Sampah. \\ Dalam Undang-Undang Nomor 18} Tahun 2008 instrumen ekonomik diatur dalam ketentuan Pasal 21 sebagai berikut :

(1) Pemerintah memberikan :

a. insentif kepada setiap orang yang melakukan pengurangan sampah; dan

b. disintensif kepada setiap orang yang tidak melakukan pengurangan sampah.

(2) Ketentuan lebih lanjut mengenai jenis, bentuk, dan tata cara pemberian insentif dan disinsentif sebagaimana dimaksud pada ayat (1) diatur dengan Peraturan Pemerintah.

\section{Instrumen Ekonomik dalam Peraturan} Pemerintah Nomor 82 Tahun 2001 tentang Pengelolaan Kualitas Air dan Pengendalian Pencemaran Air.

Dalam Undang-Undang Nomor 82 Tahun 2001 tentang Pengelolaan Kualitas Air dan Pengendalian Pencemaran Air, instrumen ekonomik diatur dalam Pasal 24 sebagai berikut :

(1) Setiap orang yang membuang air limbah ke prasarana dan atau sarana pengelolaan air limbah yang disediakan oleh pemerintah kabupaten/kota dikenakan retribusi.

(2) Retribusi sebagaimana dimaksud ayat (1) ditetapkan dengan peraturan daerah/kota.

7. Instrumen Ekonomik dalam

PeraturanPemerintahNomor46 
tahun2017

tentang

InstrumenEkonomi

\section{LingkunganHidup.}

Setelah melalui proses panjang pada tanggal 10 Nopember 2017 pukul 23.20 Peraturan Pemerintah tentang Instrumen Ekonomi Lingkungan Hidup (PP IELH) ditandatangani oleh Presiden Jokowi. Adanya PP IELH di maksudkan supaya negara dapat mengelola dana-dana hibah dan dana lain yang di peruntukan untuk perbaikan dan konservasi lingkungan. Namun PP ini harus segera diikuti dengan terbitnya Peraturan Presiden (Perpres) tentang Badan Layanan Umum (BLU) sebagai pengelola dana tersebut.

Dari segi instrumen,terdapattiga instrumenekonomi lingkunganhidupyang diaturdalam PP IELH,yakni instrumenperencanaanpembangunandank egiatanekonomi;

instrumenpendanaanlingkunganhidup; dan(3) instrumeninsentifdan/atau disinsentif. Apabila merujukpada tujuantujuandanpada instrumenekonomi yangdisebutdi muka, instrumen pendanaan lingkungan hidup dari PP IELH ini terkesan lebih menonjol dibanding instrumenyang lain.Sebetulnya PP IELHmencakup satu himpunanintrumen ekonomi yang lebihlebardanlebihdalamdari segi pilihandanruang lingkupnya.
Pada

saat

PPIELHterbit,tanggapanpihakindustridan pelakuekonomidiberbagaisektorterhadap PP ini sebagian besar berkenaandenganimplikasi

penerapaninstrumenekonomi pada berbagai sektorekonomi.Tanggapan semacamini

pentinguntukmenempatkankembali PP IELHdalamkeseluruhandirinya,yakni sebagai instrumenekonomi untukperencanaan pembangunan dan kegiatan ekonomi,pendanaan, serta insentif/disinsentifdalamrangka perlindungandanpengelolaanlingkunganhi dup.Terlebihlagi karena dalam sejumlahhal danderajattertentu,instrumeninstrumenekonomi tersebut bisa terkaitantara satu dengan yang lain.

Meskipun instrumen ekonomik lingkungan hidup memiliki eksistensi yuridis yang dinamis dalam berbagai ketentuan dan peraturan perundangundangan, namun masih ada beberapa kritikan dari para ahli yang menunjukkan kelemahan instrumen ekonomik. Diantaranya :

1. Menurut K.S. Kavi Kumar bahwa klasifikasi instrumen kebijakan lingkungan menjadi 2 macam, yaitu instrumen pengaturan langsung dan instrumen berdasarkan mekanisme pasar adalah menyesatkan.

2. Menurut Baumol dan Oates bahwa sebenarnya instrumen berdasarkan mekanisme pasar atau instrumen ekonomik adalah sulit untuk 
ditetapkan dalam kaitannya dengan kebutuhan informasi yang sangat banyak. Oleh sebab itu baku mutu lingkungan atau target emisi seringkali diperlukan dalam banyak hal.

3. Menurut Sterner bahwa klasifikasi antara instrumen kebijakan langsung dan instrumen berdasarkan pasar adalah lemah karena sering kali instrumen pengaturan langsung disokong oleh sanksi ekonomik ${ }^{11}$

Dari ke 3 (tiga) kritikan ahli tersebut menunjukan kelemahan instrumen ekonomik karena berkaitan dengan masalah finansial yang dapat menghambat penegakan hukum lingkungan dan environmental governance.

Dengan kelemahan tersebut eksistensi instrumen ekonomik di Indonesia masih harus diperbaiki. Apalagi menurut Penjelasan Umum angka 8 UUPPLH bahwa perbedaan mendasar antara UUPLH dan UUPPLH adalah adanya penguatan yang terdapat dalam UUPPLH tentang prinsip-prinsip perlindungan dan pengelolaan lingkungan hidup yang didasarkan pada tata kelola pemerintahan yang baik karena dalam setiap proses perumusan dan penerapan instrumen pencegahan pencemaran dan/atau kerusakan lingkungan hidup serta penanggulangan dan penegakan

\footnotetext{
${ }^{11}$ A'an Efendi, SH, MH, Hukum Lingkungan : Instrumen Ekonomik dalam Pengelolaan Lingkungan di Indonesia dan Perbandingannya dengan Beberapa Negara, PT. Citra Aditya Bakti, Bandung, 2014.h.39.
}

hukum mewajibkan pengintegrasian aspek transparansi, partisipasi,akuntabilitas, dan keadilan.

Prinsip penyelenggaraan pemerintahan yang baik dalam pengelolaan lingkungan hidup (good environmental governance) meliputi 6 aspek dalam satu rangkaian yang tidak terpisahkan $:^{12}$

1. Kedaulatan (sovereignity).

2. Kekuasaan (power).

3. Kebijakan (policy).

4. Pengendalian (controlling).

5. Pengembangan (developing).

6. Tanggungjawab(responsibility/liability)

Apabila perbedaan mendasar dan prinsip tersebut dapat diimplementasikan maka eksistensi instrumen ekonomik akan dapat mengimbangi environmental governance yang mampu berinteraksi multilevel antara local, nasional, internasional/global, tidak terbatas pada state, private, dan civil society baik secara formal maupun informal dalam memformulasi dan mengimplementasi kebijakan untuk merespons tuntutan dan masukan dari masyarakat terkait lingkungan yang bertujuan mencapai pembangunan berkelanjutan dan good environmental governance yang mampu menyelesaikan isu-isu lingkungan hidup baik lokal, nasional hingga internasional/global.

\footnotetext{
${ }^{12}$ Syahrul Machmud, DR., SH, Penegakan Hukum Lingkungan Indonesia, Graha Ilmu, Yogyakarta.h.63
} 


\section{KESIMPULAN}

Pengaturan instrumen ekonomik lingkungan hidup dalam berbagai peraturan perundang-undangan akhirnya bermuara pada PP IELH yang menunjukkan bahwa eksistensi instrumen ekonomik secara yuridis sangat jelas ketentuannya dan dinamis. Tetapi instrumen ekonomik dalam perlindungan dan pengelolaan lingkungan hidup sangat rawan dengan masalah finansial, hal ini dapat menghambat environmental governance. Sehingga eksistensi instrumen ekonomik masih harus diimbangi dengan environmental governance (proses tata kelola lingkungan hidup) dari penyelenggara pemerintahan yang berprinsip inklusivitas, akuntabilitas, efisiensi, efektivitas dan keadilan social yang membentuk dasar dari good governance sehingga tercapai good environmental governance yang dapat merefleksikan pemahaman terbaik dari struktur, fungsi, proses dan variabilitas yang terkait dan sesuai dengan system alam (ekosistem).

\section{DAFTARPUSTAKA}

1. A. Hamzah, DR., SH, Penegakan Hukum Lingkungan, Arikha Media Cipta, Jakarta.

2. A'an Efendi, SH, MH, Hukum Lingkungan : Instrumen Ekonomik dalam Pengelolaan Lingkungan di Indonesia dan Perbandingannya dengan Beberapa Negara, PT. Citra Aditya Bakti, Bandung, 2014.
3. Dinoroy Marganda Aritonang,SH,MH, Aspek Hukum Penyelenggaraan Administrasi Publik di Indonesia, PT. Refika Aditama, Bandung, 2019.

4. M. Chazienul Ulum, Rispa Ngindana, Environmental Governance : Isu, Kebijakan, dan Tata Kelola Lingkungan Hidup, UB Press, Malang, 2017.

5. Syahrul Machmud, DR., SH, Penegakan Hukum Lingkungan Indonesia, Graha Ilmu, Yogyakarta.

6. https://wri-indonesia.org > events > kuliah-umum-dan-diskusiinstrumen-e.

7. https://kumparan.com , aguspambagio > pp-no-46-tahun-2017untung-at..

8. Undang-Undang No 32 Tahun 2009 tentang Perlindungan dan Pengelolaan Lingkungan Hidup (Lembaran Negara Republik Indonesia Tahun 2009 No 140, Tambahan Lembaran Negara Republik Indonesia No 5059. 